Research Article

\title{
Evaluation of bio medical waste management practices in select health care facilities of Karnataka, India
}

\author{
Suman Gadicherla*, Hemanth Thapsey, Lalitha Krishnappa, Shivaraj N. Somanna
}

Department of Community Medicine, M.S. Ramaiah Medical College, Bengaluru 560054, Karnataka, India

Received: 22 August 2016

Revised: 20 August 2016

Accepted: 15 September 2016

\section{*Correspondence:}

Dr. Suman Gadicherla,

E-mail: sumang36@gmail.com

Copyright: (C) the author(s), publisher and licensee Medip Academy. This is an open-access article distributed under the terms of the Creative Commons Attribution Non-Commercial License, which permits unrestricted non-commercial use, distribution, and reproduction in any medium, provided the original work is properly cited.

\section{ABSTRACT}

Background: Health care sector has expanded to a great extent in both private and public sectors to cater to the needs of the increasing population of the country. Mismanagement of bio medical waste can expose health care personnel and public to various potential hazards.

Methods: Cross sectional study was conducted during September- November 2014 to assess current practices of BioMedical waste management (BMW) among the health care facilities (HCF) that had participated the selected districts level training program. Two stage sampling method was used to select eight districts and 15 HCFs in each district of Karnataka. An observational check list was used to observe macro and process areas of BMW.

Results: Efficiency of each of the process of waste management was calculated by using a scoring system. A total of 116 HCF were observed-9 large, 17 medium and 90 small. Segregation efficiency was poor in $22(24.4 \%)$ small HCFs. Disinfection was practiced in $50 \%$ of the locations observed in small HCFs. The storage efficiency was excellent in $56.3 \%$ and $57.7 \%$ among medium and small HCFs respectively. No containment of sharps was observed in $34.7 \%, 23.4 \%, 26.8 \%$ locations of small, medium and large HCFs respectively. Final disposal of waste was managed by common treatment facility in $88.8 \%$ of large and $88.2 \%$ of medium sized hospital respectively.

Conclusions: Practices of bio medical waste management need to be improved at all levels.

Keywords: Bio medical waste management, Training, Segregation efficiency

\section{INTRODUCTION}

Health care sector has expanded to a great extent to cater to the needs of the increasing population of the country. The expansion of the health sector has been in both public as well as private sector. The quantum of waste generated has also increased and mismanagement of bio medical waste can lead to spread of some of the blood borne infections and pollution of air water and land. Realizing this, Ministry of Environment \& Forests, Government of India had notified the Bio- Medical Waste (Management \& Handling) Rules 1998 under the Environment Protection Act 1971. The same has been amended and new rules have been notified in $2016 .{ }^{1}$ The rules have been framed in view of the fact that unscientific disposal of bio-medical waste (BMW) is a health hazard and hence its treatment and disposal should be done in a scientific manner. Bio medical waste management includes all activities of segregation, disinfection before disposal, containment, storage and final disposal of waste. The major challenge in sound management of bio medical waste is the attitude of Health care workers. To address this, training and retraining of health care workers will help in achieving the objectives of the BMW rules and also aid in scientific disposal of bio-medical waste.

Towards an effort to build the capacity of health care personnel in the state of Karnataka, a Training of Trainers (ToT) programme on BMW was conducted by 
Environmental Management and Policy Research Institute (EMPRI) is an autonomous institution conducting applied research on environmental issues and providing training and advisory services to government, industry and civil society. TOT was conducted for a team of six persons identified from each district as master trainers during the last quarter of 2011. These master trainers in their respective districts, over the next six months in 2012 undertook district level training programme. Health care personnel were trained in the area of bio medical waste management in both government and private sector HCFs at the district level. It is believed that the training received at district level would have an impact on the practices of bio medical waste management at their respective health centers and also the knowledge would be shared with the other health care professionals.

With this background, this endeavor was undertaken to evaluate the Bio-medical waste management practices in the health care facilities (HCF) that participated in the district level training programme.

\section{METHODS}

Cross sectional study was conducted during the period September-November 2014 to assess the current practices of Bio- Medical waste management among the health care facilities that participated in the district level training.

\section{Study unit}

HCFs which had participated at district level training programme on BMW wherein at least one of its health care personnel should have undergone training were the study unit. Health care facilities were classified as Large, medium and small sized HCF based on number of beds.

For operational purposes large hospital was defined as those above 500 beds, medium size hospital is defined as those with 100-500 beds, small hospital includes less than 100 beds like Primary Health Centre / Community Health Centre / General Practitioners clinic / Nursing Home / Lab / Blood Bank / Laboratory etc. or by any other name.

\section{Sample size}

Sample size was estimated based on the findings of situation analysis of health care facilities and Common treatment facilities undertaken under the Project"Environmentally Sound Management of Medical Wastes in India, in 2009 funded by GEF/UNIDO/GOI where it was observed that the median segregation efficiency in HCFs of Karnataka state was $43 \%$. $^{2}$ Expecting similar results with $21 \%$ relative precision and $95 \%$ confidence level, this study required a minimum of 115 centres in the state.

\section{Sampling technique}

Two stage random sampling method was adopted to select the 115 health care facilities, that had participated in the district level training on BMW.

\section{Stage 1}

To have a representative sample across the state, all the four revenue divisions were considered to select HCFs. Two districts in each of the revenue division was randomly selected using random number table. The required sample size was equally divided between the selected eight districts and hence the sample size in each district was 14-15 HCFs.

\section{Stage 2}

All the Health care facilities within the selected district which participated in the district level training on BMW constituted the sampling frame. All the HCFs were listed according to alphabetical order and a numerical identification code was given. Among them, 15 HCFs were randomly selected in each district using simple random technique.

\section{Method of data collection}

M. S. Ramaiah Medical College was the nodal centre for conducting the evaluation and Department of Community Medicine of the medical college in the respective districts were identified as coordinating centre to carry out the evaluation in their districts. Two representatives not below the rank of Assistant professors from Department of Community Medicine formed the evaluation team for the respective district and underwent training at the nodal centre (M.S. Ramaiah Medical College and Hospitals) to conduct evaluation in the selected HCFs.

A field manual was developed and was shared with each of the coordinating centers. The field manual consisted of explanation to the observational check list that was used for evaluation. The evaluation team from the coordinating centre visited the selected HCFs and evaluated the HCF for biomedical waste management practices using the observational checklist provided.

\section{Tool}

Observational check list used for assessing the Bio Medical waste management practices of the HCFs consisted of three parts which included general description of the HCFs, macro areas and processes of Bio-medical waste management. The macro areas that were evaluated were written policy on infection control and hospital waste management, presence of committees of waste management and infection control, Standard operating protocols, authorization from PCB, monitoring mechanism of waste management and injuries. Processes which were evaluated were segregation, disinfection, 
transportation and storage, containment of waste sharps. All the processes of waste management were assessed at various locations in the hospital e.g. outpatient department of different specialties (OBG, paediatrics, medicine, surgery etc.), minor OT, intensive care units, diagnostic labs, wards etc.

A scoring system was evolved and the efficiency of each of the process of waste management was calculated. The Processes of segregation, transport and storage were scored on a 0-4 point scale. A maximum score of 4 was given, when the processes was done according to BMW rules of 1998. Zero score was given if processes were not followed. The description for scoring was provided in the field manual and the evaluators were specifically trained at the nodal centre for the same. Efficiency of the processes was calculated by adding the scores of all the locations in the hospital (observed score) and dividing the observed score by maximum possible score in percentage.

For example, Segregation efficiency of the hospital was calculated by adding the observed scores of all the locations in the hospital divided by the maximum score. (Segregation efficiency: segregation score obtained/maximum segregation score possible X 100, expressed as system operating currently with __\% of efficiency).

\section{RESULTS}

Table 1: Macro areas-policy issues of Biomedical waste management in large and medium sized HCFs.

\begin{tabular}{|lll|}
\hline Macro issues & $\begin{array}{l}\text { Large } \\
(\mathbf{n = 9})\end{array}$ & $\begin{array}{l}\text { Medium } \\
(\mathbf{n}=17)\end{array}$ \\
\hline $\begin{array}{l}\text { Infection Control policy } \\
\text { present }\end{array}$ & $5(55.6 \%)$ & $2(11.8 \%)$ \\
\hline $\begin{array}{l}\text { Hospital waste } \\
\text { management policy present }\end{array}$ & $5(55.6 \%)$ & $4(28.6 \%)$ \\
\hline $\begin{array}{l}\text { Infection control } \\
\text { committee exists }\end{array}$ & $6(66.6 \%)$ & $3(17.7 \%)$ \\
\hline $\begin{array}{l}\text { Hospital waste } \\
\text { management committee } \\
\text { exists }\end{array}$ & $7(77.8 \%)$ & $8(47.0 \%)$ \\
\hline $\begin{array}{l}\text { Spill Management protocol } \\
\text { present }\end{array}$ & $3(33.3 \%)$ & $5(29.4 \%)$ \\
\hline Policy on mercury present & $2(22.2 \%)$ & $1(5.9 \%)$ \\
\hline
\end{tabular}

A total of $116 \mathrm{HCF}$ were included for analysis of which 9 were large, 17 medium and 90 small Health care facilities. Of which, $27(23.3 \%)$ HCFs were from the private sector and $89(76.7 \%)$ were from the government sector. Among the 90 small HCFs, 52 (57.8\%) were Primary health centers, $12(13.3 \%)$ were community health center and the rest 3 were clinics, 5 nursing homes. Presence of written policies and committees for infection control and hospital waste management was observed only in the large and medium sized HCFs. While only 2 of the large and only one medium hospital had mercury policy in place, none of the small HCFs had any policy in place (Table 1).

At the time of the survey $3 / 9(33.3 \%), 5 / 16(31.3 \%)$ and $15 / 76(19.7 \%)$ of large, medium and small HCFs respectively had obtained authorization from the state pollution control board but had not renewed it. Overall monitoring of injuries was satisfactory in $34 \%$ of HCF. Periodic monitoring of waste management system was undertaken with report available in $33.3 \%, 12.5 \%$ and $15.9 \%$ of large, medium and small $\mathrm{HCF}$ respectively. Waste management register was maintained in $66.7 \%$ of large; $80.0 \%$ in medium and $43.9 \%$ of small HCFs. Injury register was maintained in 20 of HCFs overall (Table 2).

Table 2: Macro areas-monitoring system related to biomedical waste management in large, medium and small HCFs.

\begin{tabular}{|c|c|c|c|}
\hline Components & Large & Medium & Small \\
\hline $\begin{array}{l}\text { i) Waste } \\
\text { Management } \\
\text { register }\end{array}$ & $(n=9)$ & $(\mathrm{n}=15)^{*}$ & $(\mathrm{n}=82)^{*}$ \\
\hline Present & $\begin{array}{l}6 \\
(66.7 \%)\end{array}$ & $\begin{array}{l}12 \\
(80.0 \%)\end{array}$ & $\begin{array}{l}36 \\
(43.9 \%)\end{array}$ \\
\hline Absent & $\begin{array}{l}3 \\
(33.3 \%)\end{array}$ & $3(20.0 \%)$ & $46(56.1 \%)$ \\
\hline ii) Injury register & $(n=9)$ & $(n=14)^{*}$ & $(n=84)^{*}$ \\
\hline Present & $\begin{array}{l}2 \\
(22.2 \%)\end{array}$ & $\begin{array}{l}4 \\
(28.6 \%)\end{array}$ & $14(16.7 \%)$ \\
\hline Absent & $7(77.8 \%)$ & $\begin{array}{l}10 \\
(71.4 \%)\end{array}$ & $70(83.3 \%)$ \\
\hline $\begin{array}{l}\text { iii) Monitoring } \\
\text { of injuries }\end{array}$ & $(n=9)$ & $(n=17)$ & $(\mathrm{n}=87)^{*}$ \\
\hline Not satisfactory & $\begin{array}{l}4 \\
(44.4 \%)\end{array}$ & $\begin{array}{l}11 \\
(64.7 \%)\end{array}$ & $\begin{array}{l}60 \\
(69.0 \%)\end{array}$ \\
\hline Satisfactory & $\begin{array}{l}5 \\
(55.5 \%)\end{array}$ & $6(35.3)$ & $27(31.0)$ \\
\hline $\begin{array}{l}\text { iv) Periodic } \\
\text { monitoring of } \\
\text { waste } \\
\text { management } \\
\text { system }\end{array}$ & $(n=9)$ & $(\mathrm{n}=16)^{*}$ & $(\mathrm{n}=88)^{*}$ \\
\hline $\begin{array}{l}\text { No monitoring } \\
\text { and reports }\end{array}$ & $\begin{array}{l}2 \\
(22.2 \%)\end{array}$ & $8(50 \%)$ & $\begin{array}{l}28 \\
(31.8 \%)\end{array}$ \\
\hline $\begin{array}{l}\text { Monitoring } \\
\text { undertaken but } \\
\text { no reports }\end{array}$ & $\begin{array}{l}4 \\
(44.4 \%)\end{array}$ & $\begin{array}{l}6 \\
(37.5 \%)\end{array}$ & $\begin{array}{l}23 \\
(26.1 \%)\end{array}$ \\
\hline $\begin{array}{l}\text { Monitoring } \\
\text { undertaken and } \\
\text { with reports }\end{array}$ & $\begin{array}{l}3 \\
(33.3 \%)\end{array}$ & $\begin{array}{l}2 \\
(12.5 \%)\end{array}$ & $\begin{array}{l}14 \\
(15.9 \%)\end{array}$ \\
\hline Not applicable\# & - & - & $\begin{array}{l}23 \\
(26.1 \%)\end{array}$ \\
\hline
\end{tabular}

*n varied as there were missing information in the proforma \# NA- Small HCF which did not have beds were not considered

The median quantum of waste generated across the different sizes of HCFs in the yellow colour code that 
includes human anatomical waste was 40, 30 and 66.7 gms / day in large medium and small HCFs respectively. Quantum of waste in the yellow colour code in the small HCFs was observed to be more than that in the medium and large size HCFs. The reason for the same could be that the segregation efficiency was observed to be poor and average among $50 \%$ of the small HCFs (Table 3).

Table 3: Quantum of waste as per different sizes of HCFs.

\begin{tabular}{|llll|}
$\begin{array}{l}\text { Colour } \\
\text { code }\end{array}$ & $\begin{array}{l}\text { Large } \\
\text { median } \\
\text { (IQR) }\end{array}$ & $\begin{array}{l}\text { Medium } \\
\text { median } \\
\text { (IQR) }\end{array}$ & $\begin{array}{l}\text { Small } \\
\text { median } \\
\text { (IQR) }\end{array}$ \\
\hline \multirow{2}{*}{ Yellow } & $\begin{array}{l}40.0(17.3- \\
75.6)\end{array}$ & $\begin{array}{l}30.0(20.0- \\
55.0)\end{array}$ & $\begin{array}{l}66.7(30.8- \\
166.7)\end{array}$ \\
\hline \multirow{2}{*}{ Red } & $31.6(13.8-$ & $20.0(20.0-$ & $40.0(31.7-$ \\
& $108.8)$ & $32.5)$ & $83.3)$ \\
\hline \multirow{2}{*}{ Blue } & $22.8(14.9-$ & $27.5(20.0-$ & $66.7(33.3-$ \\
& $142.5)$ & $60.0)$ & $166.7)$ \\
\hline White & $20.0(13.5-$ & $10.0(9.0-$ & $66.7(26.7-$ \\
translucent & $192.3)$ & $20.0)$ & $155.0)$ \\
\hline \multirow{2}{*}{ Black } & $22.3(8.8-$ & $45.0(15.0-$ & $33.3(28.6-$ \\
& $728.7)$ & $60)$ & $100.0)$ \\
\hline
\end{tabular}

Table 4: Efficiency score for key processes of Biomedical waste management.

\begin{tabular}{|c|c|c|c|c|}
\hline $\begin{array}{l}\text { Efficiency } \\
\text { score }\end{array}$ & n $(\%)$ & n $(\%)$ & n $(\%)$ & n $(\%)$ \\
\hline Segregation & $\begin{array}{l}\text { Large } \\
\mathrm{n}=9\end{array}$ & $\begin{array}{l}\text { Medium } \\
\mathrm{n}=17\end{array}$ & $\begin{array}{l}\text { Small } \\
\mathrm{n}=90\end{array}$ & $\begin{array}{l}\text { Total } \\
n=116\end{array}$ \\
\hline Poor (0-25) & Nil & Nil & $\begin{array}{l}22 \\
(24.4 \%)\end{array}$ & $\begin{array}{l}22 \\
(19.0 \%)\end{array}$ \\
\hline $\begin{array}{l}\text { Average } \\
(26-50)\end{array}$ & $\begin{array}{l}2 \\
(22.2 \%)\end{array}$ & $4(23.5 \%)$ & $\begin{array}{l}24 \\
(26.7 \%)\end{array}$ & $\begin{array}{l}30 \\
(25.9 \%)\end{array}$ \\
\hline $\begin{array}{l}\text { Good (51- } \\
75)\end{array}$ & $\begin{array}{l}3 \\
(33.3 \%)\end{array}$ & $6(35.3 \%)$ & $\begin{array}{l}23 \\
(25.6 \%)\end{array}$ & $\begin{array}{l}32 \\
(27.6 \%)\end{array}$ \\
\hline $\begin{array}{l}\text { Excellent } \\
(76-100)\end{array}$ & $\begin{array}{l}4 \\
(44.4 \%)\end{array}$ & $7(41.2 \%)$ & $\begin{array}{l}21 \\
(23.3 \%)\end{array}$ & $\begin{array}{l}32 \\
(27.6 \%)\end{array}$ \\
\hline $\begin{array}{l}\text { Transportati } \\
\text { on of waste }\end{array}$ & $\begin{array}{l}\text { Large } \\
n=5\end{array}$ & $\begin{array}{l}\text { Medium } \\
\mathrm{n}=15\end{array}$ & $\begin{array}{l}\text { Small } \\
\mathrm{n}=54^{*}\end{array}$ & $\begin{array}{l}\text { Total } \\
\mathrm{N}=74\end{array}$ \\
\hline Poor (0-25) & $\begin{array}{l}1 \\
(20.0 \%)\end{array}$ & $3(20.0 \%)$ & $\begin{array}{l}20 \\
(37.0 \%)\end{array}$ & $\begin{array}{l}24 \\
(32.4 \%)\end{array}$ \\
\hline $\begin{array}{l}\text { Average } \\
(26-50)\end{array}$ & $\begin{array}{l}2 \\
(40.0 \%)\end{array}$ & $1(6.7 \%)$ & $\begin{array}{l}11 \\
(20.4 \%)\end{array}$ & $\begin{array}{l}14 \\
(18.9 \%)\end{array}$ \\
\hline $\begin{array}{l}\text { Good (51- } \\
75)\end{array}$ & 0 & $5(33.3 \%)$ & $\begin{array}{l}11 \\
(20.4 \%)\end{array}$ & $\begin{array}{l}16 \\
(21.6 \%)\end{array}$ \\
\hline $\begin{array}{l}\text { Excellent } \\
(76-100)\end{array}$ & $\begin{array}{l}2 \\
(40.0 \%)\end{array}$ & $6(40.0 \%)$ & $\begin{array}{l}12 \\
(22.2 \%)\end{array}$ & $\begin{array}{l}20 \\
(27.0 \%)\end{array}$ \\
\hline $\begin{array}{l}\text { Storage of } \\
\text { waste }\end{array}$ & $\begin{array}{l}\text { Large* } \\
\mathrm{n}=8\end{array}$ & $\begin{array}{l}\text { Medium* } \\
\mathrm{n}=16\end{array}$ & $\begin{array}{l}\text { Small* } \\
n=52\end{array}$ & $\begin{array}{l}\text { Total } \\
\mathrm{n}=76\end{array}$ \\
\hline Poor (0-25) & 0 & $3(18.8 \%)$ & $\begin{array}{l}11 \\
(21.2 \%)\end{array}$ & $\begin{array}{l}14 \\
(18.4 \%)\end{array}$ \\
\hline $\begin{array}{l}\text { Average } \\
(26-50)\end{array}$ & $\begin{array}{l}4 \\
(50.0 \%)\end{array}$ & $3(18.8 \%)$ & $\begin{array}{l}7 \\
(13.5 \%)\end{array}$ & $\begin{array}{l}14 \\
(18.4 \%)\end{array}$ \\
\hline $\begin{array}{l}\text { Good (51- } \\
75)\end{array}$ & $\begin{array}{l}2 \\
(25.0 \%)\end{array}$ & $1(6.3 \%)$ & $\begin{array}{l}4 \\
(7.7 \%)\end{array}$ & $\begin{array}{l}7 \\
(9.2 \%)\end{array}$ \\
\hline $\begin{array}{l}\text { Excellent } \\
(76-100)\end{array}$ & $\begin{array}{l}2 \\
(25.0 \%)\end{array}$ & $9(56.3 \%)$ & $\begin{array}{l}30 \\
(57.7 \%)\end{array}$ & $\begin{array}{l}41 \\
(53.9 \%)\end{array}$ \\
\hline
\end{tabular}

It is observed that segregation efficiency in the medium and large HCFs was average to excellent, while segregation efficiency was poor in $22(24.4 \%)$ of small HCFs (Table 4).

Information on transportation efficiency was available for only 74 HCFs as against 116 as it was not applicable in some of the small HCFs such as primary health centers and centers with no beds (no inpatient facility). Overall transportation efficiency was excellent in $27.0 \%$ of HCFs and good in $21.6 \%$ of HCF (Table 4 ).

Efficiency of Storage of waste varied from average to excellent among the large hospitals. The storage efficiency was excellent in $56.3 \%$ and $57.7 \%$ among medium and small HCFs respectively (Table 4).

Disinfection process was observed at different locations of the HCFs. Among the 354 locations observed, in small $\mathrm{HCFs} 50 \%$ of them practiced disinfection before disposal of waste (Table 5).

Table 5: Disinfection practices in various locations of health care facilities.

\begin{tabular}{|lll|l|}
\hline HCF & $\begin{array}{l}\text { Large } \mathbf{n} \\
(\%)\end{array}$ & $\begin{array}{l}\text { Medium } \\
\mathbf{n}(\%)\end{array}$ & $\begin{array}{l}\text { Small } \mathbf{n} \\
(\%)\end{array}$ \\
\hline $\begin{array}{l}\text { No. of locations } \\
\text { observed }\end{array}$ & $\mathrm{n}=90$ & $\mathrm{n}=121$ & $\mathrm{n}=354$ \\
\hline $\begin{array}{l}\text { Disinfection } \\
\text { practiced }\end{array}$ & $\begin{array}{l}60 \\
(66.6 \%)\end{array}$ & $\begin{array}{l}78 \\
(64.5 \%)\end{array}$ & $\begin{array}{l}175 \\
(49.4 \%)\end{array}$ \\
\hline $\begin{array}{l}\text { Disinfection not } \\
\text { practiced }\end{array}$ & $\begin{array}{l}40 \\
(33.4 \%)\end{array}$ & $\begin{array}{l}43 \\
(35.5 \%)\end{array}$ & $\begin{array}{l}179 \\
(50.6 \%)\end{array}$ \\
\hline
\end{tabular}

Table 6: Sharps management practices in various locations of health care facilities.

\begin{tabular}{|c|c|c|c|}
\hline $\mathrm{HCF}$ & $\begin{array}{l}\text { Large } \\
\text { n }(\%)\end{array}$ & $\begin{array}{l}\text { Medium } \\
\text { n }(\%)\end{array}$ & $\begin{array}{l}\text { Small } \\
\mathrm{n}(\%)\end{array}$ \\
\hline $\begin{array}{l}\text { No of locations } \\
\text { observed }\end{array}$ & 95 & 107 & 299 \\
\hline $\begin{array}{l}\text { Sharps are disinfected } \\
\text { and contained in } \\
\text { puncture proof } \\
\text { container }\end{array}$ & $\begin{array}{l}41 \\
(43.2)\end{array}$ & $50(46.7)$ & $\begin{array}{l}111 \\
(37.1)\end{array}$ \\
\hline $\begin{array}{l}\text { Sharps are contained in } \\
\text { puncture proof } \\
\text { container without } \\
\text { disinfection }\end{array}$ & $\begin{array}{l}12 \\
(12.6)\end{array}$ & $9(8.4)$ & $\begin{array}{l}47 \\
(15.7)\end{array}$ \\
\hline $\begin{array}{l}\text { Sharps are burnt using } \\
\text { needle burner }\end{array}$ & $7(7.4)$ & $9(8.4)$ & $\begin{array}{l}26 \\
(8.7)\end{array}$ \\
\hline $\begin{array}{l}\text { Sharps are disfigured } \\
\text { with needle/ hub cutter } \\
\text { and disinfected }\end{array}$ & $2(2.1)$ & $14(13.1)$ & $\begin{array}{l}35 \\
(11.7)\end{array}$ \\
\hline None of the above & $\begin{array}{l}33 \\
(34.7)\end{array}$ & $25(23.4)$ & $\begin{array}{l}80 \\
(26.8)\end{array}$ \\
\hline
\end{tabular}

Containment of sharps is important irrespective of the size of the HCFs. In $43.2 \%, 46.7 \%$ and $37.1 \%$ of the 
locations in large, medium and small HCFs respectively had correct practice of disinfection and proper containment of sharps. It was observed that no specific practice was done for sharps in $34.7 \%, 23.4 \%$ and $26.8 \%$ of locations in large, medium and small HCFs respectively (Table 6).

Waste was handed over to common treatment facility in $8 / 9(88.8 \%)$ of Large, and $15 / 17(88.2 \%)$, of medium sized hospital. Whereas in small HCF, only 42 out of 90 $\mathrm{HCF}(46.7 \%)$ handed over health care waste to common treatment facility and 48/ $90(53.3 \%)$ managed their waste on-site for final disposal. Among the onsite managed small HCF, 38 (79.1\%) had Waste Sharp pits and $40(83.3 \%)$ had deep burial facility.

It was observed that nearly about $50 \%$ of the HCFs used Liquid waste management system developed by Karnataka Health Systems Development Reforms Project for disinfecting liquid waste before disposal. Only one large hospital had an effluent treatment plant of its own. No specific treatment of liquid waste was observed in 17 (14.6\%) of all the HCFs put together.

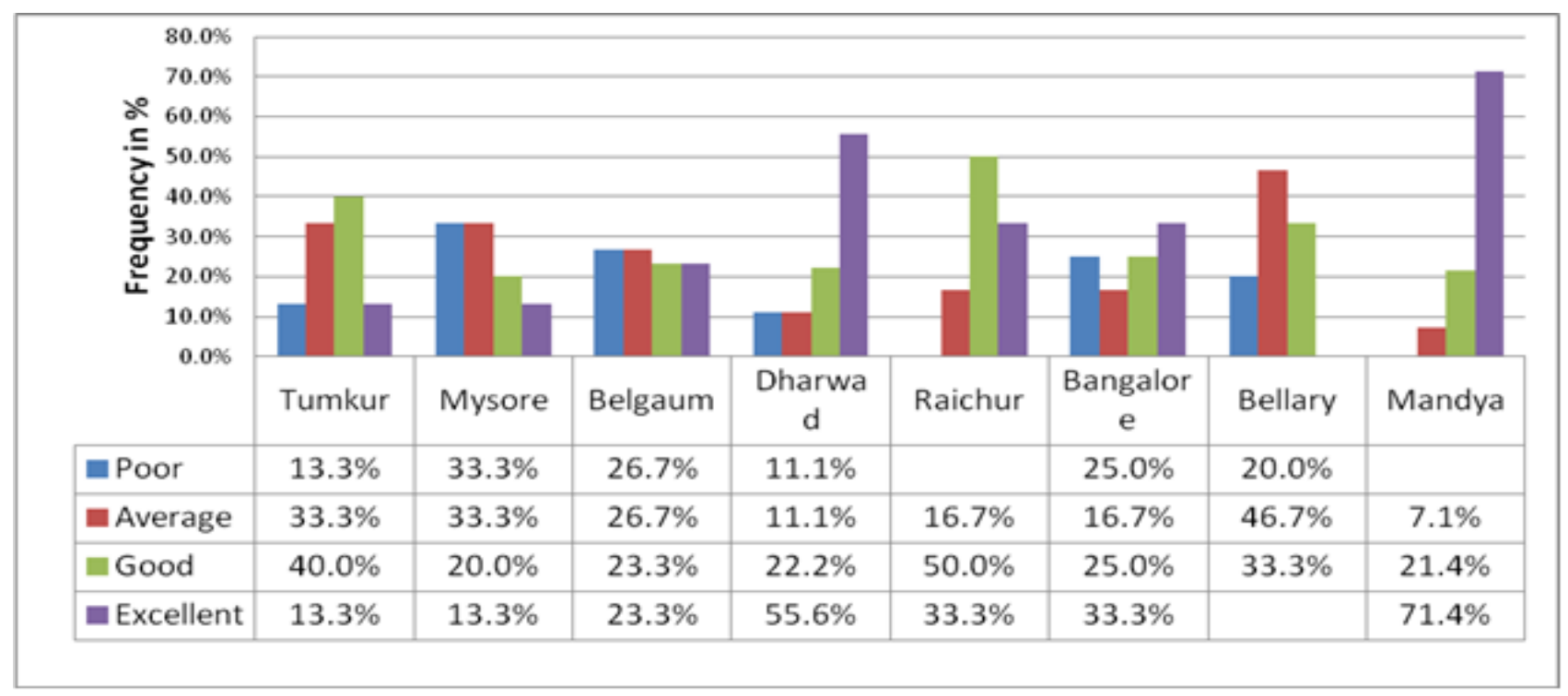

Figure 1: District-wise comparison of segregation efficiency of waste management.

\section{DISCUSSION}

Infection control and hospital waste management policies and committees are guiding forces for good practices in large and medium sized hospitals. It ensures establishment of effective and safe management of bio medical waste in the health care institutions. Regular monitoring of bio medical waste management ensures occupational safety of health care personnel and also further strengthens the waste management systems.

It was observed in the present study, policies for bio medical waste and infection control was observed in only $50 \%$ of the large hospitals. Monitoring of injuries, waste management systems and documentation was not satisfactory in majority of health care facilities found across the different categories of HCFs studied.

Information from the state pollution control boards (2007-08) state that $53.25 \%$ of health care establishments are in operation without obtaining authorization from their respective state pollution control boards. Approximately $56.87 \%$ of 506.74 tons of health care waste generated is being treated through 159 common bio medical waste treatment facilities. ${ }^{3}$ In 2014 state pollution control board of Karnataka had identified 26,927 HCFs; and 27 common treatment facilities in the state. ${ }^{2}$ Quantum of infectious waste generated in a tertiary care hospital was $101 \mathrm{Kg}$ per day. ${ }^{5}$ The median quantum of infectious waste generated in our study was 31.6 gms /day (IQR 13.8-108.8) among large hospital. However, the information on the quantum of waste generated was not forthcoming in most of the places. Quantum of waste generated could not be ascertained accurately as there was a mix up general and bio medical waste. ${ }^{6}$ The observation regarding the quantum of waste generated in the HCFs depends on: good documentation procedures, the time of visit of the investigating team, frequency with which bio medical waste is collected from the HCFs by the common treatment facilities and segregation practices followed at the HCFs. Documentation of quantum of waste generated by the HCFs in mandated as per BMW rules.

Study on current practices of health care waste management in small health care facilities in one of the wards under BBMP area revealed that segregation at the 
point of generation was observed in $22(62.9 \%)$ of $\mathrm{HCF}$ and segregation process was complaint as per BMW rules of 1998 in only $5(16.1 \%)$ of HCFs. Containment of sharps and disinfection process was found to be deficient in most of the centres. ${ }^{6}$

Situational analysis of bio medical waste management done in the 25 districts of 20 states of India in 388 health facilities (194 public+194 private); revealed that $82 \%$ of primary care, $60 \%$ of secondary and $54.2 \%$ of tertiary care facilities were in RED zone with no credible waste management system in place. ${ }^{7}$ Mean percentage scores for condition of the receptacles, segregation, mutilation and disinfection of waste at the emergency room of a tertiary care hospital in North India was $87 \%, 92 \%, 85 \%$ and $86 \%$ respectively. Comparison of different areas of the hospitals showed there was no statistically significant difference with regard to segregation of waste and condition of waste receptacles. ${ }^{8}$

In the present study, it was observed that the segregation efficiency in small facilities was distributed equally among grades of poor to excellent. However, $77.7 \%$ of the large and $76.4 \%$ of the medium sized HCFs and $48.8 \%$ of the small HCFs were observed to have segregation efficiency of good and excellent. The findings of the present study are similar to that of the above mentioned studies.

Transportation efficiency among the large HCFs- $60 \%$ of them had an efficiency of poor to average, $26.6 \%$ of medium sized HCFs showed a transport efficiency of poor to average. A median score of 5 (IQR 5-5) 5 (IQR 56.7) was observed for process of transportation in secondary and tertiary care hospitals respectively. ${ }^{7}$ Adequate importance has to be given to in house as well as transportation to common treatment facility to achieve safe management of bio medical waste management.

Median score for storage was 4 (IQR1.1- 7) and 6 (IQR 2.5-8) in secondary and tertiary care hospitals respectively. ${ }^{7}$ Storage efficiency was good to excellent in $50 \%$ of large HCFS and in $62.5 \%$ of medium sized hospitals. Storage facility for bio medical waste should have facilities to maintain the segregation and should be accessible to only authorized personnel. Often this aspect of storage is neglected in the planning phase of the health care facility.

It was observed in the present study that the efficiency of transportation and storage also need improvement. Disinfection of waste at the point of generation reduces the chances of transmission of infections among health care personnel and general public at large but is not practiced at all the locations of health care facility. Sharps have the potential to transmit infection like HIV and Hepatitis B and it was observed that about one third of the locations did not practice safe management of sharps. Liquid waste management is one of the neglected areas of bio medical waste management. However in the present study it was found that in more than $75 \%$ of health care facilities were disposing their liquid waste safely.

Bio Medical waste management is beyond just compilation of the data on process and enforcement of regulations; it has to be supported by appropriate education, training, commitment of health care staff within an effective policy frame work. ${ }^{9}$

\section{CONCLUSION}

Bio medical waste management is more of human attitudinal issue than technological. Hence, it is important that training programmes give equal importance to address issues of attitudinal change across all categories of health care personnel for sustenance of sound and safe Bio medical waste management practices. Segregation at source of generation being the heart of waste management processes needs to be strengthened by regular monitoring With amended BMW rule of 2016 in place, it is imperative that all the personnel involved in waste management need to be re-trained in this regard.

The evaluation was conducted post training and baseline information on Bio medical waste management systems before training was not available for comparison.

\section{ACKNOWLEDGEMENTS}

Principal and Dean of M.S. Ramaiah Medical college, Environmental Management and Policy Research Institute, Department of Forest, Ecology and Environment, Government of Karnataka, Bangalore, all the investigators of the coordinating departments of Community Medicine of the eight medical colleges.

Funding: Environmental Management and Policy Research Institute, Department of Forest, Ecology and Environment, Government of Karnataka, Bangalore Conflict of interest: None declared

Ethical approval: Not required

\section{REFERENCES}

1. Ministry of Environment, Forest and Climate Change. The Gazette of India Notification, Published by authority: Extraordinary Part II section 3- sub section (I). New Delhi, 28th March, 2016 available

at http://www.moef.nic.in/sites/default/files/BMW\%20 Rules,\%202016_1.pdf. Accessed on 22 ${ }^{\text {nd }}$ August 2016.

2. Unpublished report of Situation analysis of health care facilities and Common treatment facilities undertaken under the Project-"Environmentally Sound Management of Medical Wastes in India", in 2009 funded by Global Environment Fund, UNIDO and Government of India. 
3. Mohankumar S, Kottaiveeran K. Hospital Waste Management and Environmental Problems in India. International J Pha Bio Arc. 2011;2(6):1621-6.

4. Status of BMW in Karnataka state.doc. http://kspcb.gov.in/Status\%20of\%20BMW\%20in\% 20Karnataka\%20state.pdf. Accessed on 3rd August 2016.

5. Patil GV, Pokherl K. Biomedical solid waste management in an Indian hospital: a case study. Waste manag. 2005;25(6)592-9.

6. Chethana T, Thapsey H, Gautham MS, Pruthvish S, suryanarayana SP. J Community Health. 2014;39:310-15.

7. INCLEN Program Evaluation Network (IPEN) study group, New Delhi, India. Bio-medical waste management: situational analysis and predictors of performances in 25 districts across 20 Indian States. Indian J Med Res. 2014;139:141-53.

8. Rajiv K, Anil KG, Arun KA, Ashok KA. Descriptive study on evaluation of bio-medical waste management in a tertiary care public hospital of North India. J Environ Health Sci Eng. 2014;12:69.

9. Gupta S, Boojh R, Mishra A, Chandra H. Rules and management of biomedical waste at Vivekananda Polyclinic: a case study. Waste Manag. 2009;29(2):812-9.

Cite this article as: Gadicherla $\mathrm{S}$, Thapsey $\mathrm{H}$, Krishnappa L, Somanna SN. Evaluation of Bio medical waste management practices in select health care facilities of Karnataka, India. Int J Community Med Public Health 2016;3:2722-8. 